\title{
CpG island methylation is a common finding in colorectal cancer cell lines
}

\author{
CM Suter', M Norrie', ${ }^{1,2}$ SL Ku', KF Cheong', I Tomlinson ${ }^{3}$ and RL Ward*,1,2 \\ 'Department of Medical Oncology, St Vincent's Hospital, Victoria St, Darlinghurst, NSW 20 I0, Australia; ${ }^{2}$ School of Medicine, University of New South \\ Wales, Sydney, NSW 2052, Australia; ${ }^{3}$ Molecular and Population Genetics Laboratory, Cancer Research UK, London WC2A 3PX, UK
}

\begin{abstract}
Tumour cell lines are commonly used in colorectal cancer (CRC) research, including studies designed to assess methylation defects. Although many of the known genetic aberrations in CRC cell lines have been comprehensively described, no studies have been performed on their methylation status. In this study, 30 commonly used CRC cell lines as well as seven primary tumours from individuals with hereditary nonpolyposis colorectal cancer (HNPCC) were assessed for methylation at six CpG islands known to be hypermethylated in colorectal cancer: hMLHI, pl6, methylated in tumour (MINT-)-I, -2, - I2 and -3I. The cell lines were also assessed for microsatellite instability (MSI), ploidy status, hMLHI expression, and mutations in APC and Ki-ras. Methylation was frequently observed at all examined loci in most cell lines, and no differences were observed between germline-derived and sporadic cell lines. Methylation was found at MINT I in 63\%, MINT 2 in 57\%, MINT 12 in 7I\%, MINT 3I in 53\%, pl6 in 7I\%, and hMLHI in $30 \%$ of cell lines. Overall only one cell line, SWI4I7, did not show methylation at any locus. Methylation was found with equal frequency in MSI and chromosomally unstable lines. MSI was over-represented in the cell lines relative to sporadic CRC, being detected in $47 \%$ of cell lines. The rate of codon 13 Ki-ras mutations was also over three times that expected from in vivo studies. We conclude that CPG island hypermethylation, whether acquired in vivo or in culture, is a ubiquitous phenomenon in CRC cell lines. We suggest that CRC cell lines may be only representative of a small subset of real tumours, and this should be taken into account in the use of CRC cell lines for epigenetic studies.

British Journal of Cancer (2003) 88, 4I3-419. doi:I0.1038/sj.bjc.6600699 www.bjcancer.com

(c) 2003 Cancer Research UK
\end{abstract}

Keywords: colorectal carcinoma; methylation; microsatellite instability; CpG island

It is generally accepted that colorectal cancer (CRC) usually develops via one of two pathways-chromosomal instability (Kinzler and Vogelstein, 1996) or microsatellite instability (MSI) (Ionov et al, 1993). The molecular genetics of both these pathways are among the best understood of all human cancers. Recently, a third classification of CRC has emerged-the CpG island methylator phenotype (CIMP) (Toyota et al, 1999a). This classification is primarily based on the methylation status of certain sites in the genome, termed MINT loci, which are preferentially methylated in tumours. CIMP tumours are a subset of CRC with distinct clinicopathological characteristics and have been found to be associated with MSI (Ahuja et al, 1997; Hawkins et al, 2002).

Cell lines are widely used in CRC research, including studies on methylation, and are generally thought to be representative of the disease. Several groups have studied many commonly used cell lines at the genetic level, and generally the genetic changes in cell lines do reflect the changes seen in vivo (Ilyas et al, 1997; Rowan et al, 2000; Gayet et al, 2001; Woodford-Richens et al, 2001). However, despite the increased use of colorectal cell lines for epigenetic studies, there have been no comprehensive studies of the propensity for methylation in these cell lines.

*Correspondence: Dr RL Ward; E-mail: r.ward@garvan.unsw.edu.au Received 26 September 2002; accepted 9 October 2002
In this study, we have examined the methylation status of four informative MINT loci, and the $p 16$ and $h M L H 1$ promoter, in 30 commonly used CRC cell lines. The aim of this study was to determine the frequency of $\mathrm{CpG}$ island hypermethylation in these cell lines, and determine if the epigenetic profile of these cell lines reflects that seen in primary colorectal tumours.

\section{MATERIALS AND METHODS}

Methylation frequency in the set of sporadic tumours reported in the analysis was determined in a previous study of 417 prospectively collected tumours (Hawkins et al, 2002). Also included in the current analysis were seven primary tumours from seven individuals with a proven germline mutation in a mismatch repair gene (five $h M S H 2$ and two $h M L H 1$ ). These primary tumours were collected as fresh representative tissue samples from consenting individuals undergoing surgical resection at the St Vincent's Campus. The 30 human colorectal cell lines examined in this study are listed in Table 1. All cell lines were either originally derived from the ATCC, or received as kind gifts. Cells were cultured in DMEM, EMEM or RPMI, all supplemented with $10 \%$ foetal calf serum, and were harvested when growing exponentially. DNA was extracted from fresh tissue and cell lines using standard methods. 
Table I Genetic and epigenetic changes in 30 CRC cell lines

Methylation

\begin{tabular}{|c|c|c|c|c|c|c|c|c|c|c|c|c|}
\hline Cell line & $\begin{array}{l}\text { MSI } \\
\text { status }\end{array}$ & $\begin{array}{l}\text { APC } \\
\text { defect }\end{array}$ & $\begin{array}{l}\text { K-ras } \\
\text { mutation }\end{array}$ & Ploidy & $\begin{array}{l}\text { MLHI } \\
\text { expression }\end{array}$ & MLHI-A & MLHI-C & pl6 & MINT-I & MINT-2 & MINT-I 2 & MINT-3 I \\
\hline SW620 & MSS & Unknown & Codon 12 & Aneuploid & Positive & $\cup$ & $\cup$ & $M$ & $\cup$ & $P$ & $U$ & $U$ \\
\hline $\mathrm{Cl} 70$ & MSS & Unknown & None found & Diploid & Positive & $U$ & $\cup$ & NA & $P$ & $U$ & $P$ & $M$ \\
\hline COLO74I & MSS & None found & None found & Unknown & ND & NA & $\cup$ & NA & $\cup$ & $M$ & $U$ & $\cup$ \\
\hline COLO205 & MSS & Biallelic & None found & Aneuploid & Positive & $\cup$ & $\cup$ & $M$ & $P$ & $M$ & $P$ & $P$ \\
\hline SWIII6 & MSS & Biallelic & Codon 12 & Unknown & ND & $U$ & NA & $M$ & $P$ & $U$ & NA & $U$ \\
\hline SWI4I7 & MSS & Biallelic & Codon 13 & Aneuploid & ND & $U$ & $\cup$ & $\cup$ & $U$ & $U$ & $U$ & $U$ \\
\hline SW403 & MSS & Biallelic & Codon 12 & Aneuploid & Positive & $M$ & $U$ & $\cup$ & $U$ & $U$ & $U$ & $U$ \\
\hline SW480 & MSS & Biallelic & Codon 12 & Aneuploid & Positive & $U$ & $U$ & $M$ & $U$ & $M$ & NA & $U$ \\
\hline SKCOI & MSS & Biallelic & Codon 12 & Aneuploid & ND & $M$ & $U$ & $\cup$ & $P$ & $\cup$ & $\cup$ & $P$ \\
\hline SWI 222 & MSS & Biallelic & Codon 13 & Aneuploid & ND & $\cup$ & $U$ & $\cup$ & $\cup$ & $M$ & $P$ & $P$ \\
\hline COLO320DM & MSS & Biallelic & None found & Diploid & Positive & $\cup$ & $\cup$ & $M$ & $\cup$ & $\cup$ & $P$ & $\cup$ \\
\hline SW948 & MSS & Biallelic & None found & Aneuploid & ND & $\cup$ & $\cup$ & $M$ & $P$ & $U$ & $P$ & $\cup$ \\
\hline T84 & MSS & Biallelic & Codon 13 & Aneuploid & Positive & $U$ & $U$ & $M$ & $P$ & $U$ & $P$ & $\cup$ \\
\hline $\mathrm{CACO} 2$ & MSS & Biallelic & None found & Aneuploid & Positive & $U$ & $\cup$ & $M$ & $P$ & $P$ & $P$ & $P$ \\
\hline HТ29 & MSS & Biallelic & None found & Aneuploid & Positive & $U$ & $\cup$ & $M$ & $P$ & $P$ & $P$ & $P$ \\
\hline SW837 & MSS & Biallelic & Codon 12 & Aneuploid & ND & $U$ & NA & $M$ & $P$ & $P$ & $P$ & $P$ \\
\hline $\operatorname{LIM}|2| 5^{\mathrm{a}}$ & MSI & Unknown & Codon 13 & Diploid & Negative & $U$ & $\cup$ & $\cup$ & $\cup$ & $U$ & $U$ & $P$ \\
\hline LIM24I2 & MSI & Unknown & None found & Diploid & Negative & $P$ & $P$ & $M$ & $U$ & $U$ & $P$ & $U$ \\
\hline $\mathrm{SNU}-\mathrm{C} 2 \mathrm{~B}$ & MSI & Unknown & Codon 12 & Unknown & Positive & $\cup$ & $P$ & $\cup$ & $P$ & $P$ & $P$ & $P$ \\
\hline НСТ8 & MSI & Unknown & Codon 13 & Diploid & Positive & $\cup$ & $\cup$ & $M$ & $P$ & $P$ & $P$ & $U$ \\
\hline $\mathrm{RKO}$ & MSI & Unknown & None found & Unknown & Negative & $M$ & $M$ & $M$ & $P$ & $P$ & $P$ & $P$ \\
\hline $\mathrm{LSI} / 74 \mathrm{~T}^{\mathrm{a}}$ & MSI & None found & Codon 12 & Diploid & Negative & $M$ & $M$ & $\cup$ & $U$ & $P$ & $U$ & $U$ \\
\hline HCA7 & MSI & None found & None found & Diploid & ND & $M$ & $M$ & $M$ & $U$ & $U$ & $U$ & $U$ \\
\hline SW48 & MSI & None found & None found & Diploid & Negative & $M$ & $M$ & $M$ & $P$ & $P$ & $M$ & $P$ \\
\hline $\mathrm{HCTI} 16^{\mathrm{a}}$ & MSI & None found & Codon 13 & Aneuploid & Negative & $U$ & $\cup$ & $P$ & $P$ & $P$ & $P$ & $P$ \\
\hline GP2D ${ }^{a}$ & MSI & Biallelic & Codon 12 & Diploid & ND & $U$ & $U$ & $U$ & $P$ & $M$ & $U$ & $U$ \\
\hline HCTI5N & MSI & Biallelic & Codon 13 & Aneuploid & Positive & $U$ & $\cup$ & $M$ & $\cup$ & $P$ & $P$ & $P$ \\
\hline LOVOc & $\mathrm{MSI}$ & Biallelic & Codon 13 & Diploid & Positive & $U$ & $U$ & $M$ & $P$ & $U$ & $P$ & $P$ \\
\hline LS4I I ${ }^{a}$ & MSI & Biallelic & None found & Diploid & Negative & $P$ & $P$ & $M$ & $P$ & $U$ & $P$ & $P$ \\
\hline DLD- $\left.\right|^{b}$ & $\mathrm{MSI}$ & Biallelic & Codon 13 & Diploid & Positive & $\cup$ & U & M & $P$ & $P$ & $P$ & $P$ \\
\hline
\end{tabular}

${ }^{\mathrm{a}} \mathrm{MLHI}$ germline mutation. ${ }^{\mathrm{b}} \mathrm{MSH} 6$ germline mutation. $\mathrm{MSS}=$ microsatellite stable; $\mathrm{MSI}=$ microsatellite instability; $\mathrm{M}=$ methylated; $\mathrm{U}=$ unmethylated; $\mathrm{P}=$ partially methylated; $\mathrm{NA}=$ not amplifiable; $\mathrm{ND}=$ not done. ${ }^{\mathrm{MSH}} 2$ germline mutation.

We have reported the APC status of each cell line previously (Rowan et al, 2000). Mutations in the first and second bases of codon 12 of Ki-ras were detected by REMS-PCR as described (Ward et al, 1998). An RFLP method was developed for the detection of Ki-ras codon 13 mutations. Genomic DNA $(500 \mathrm{ng})$ was used in PCR with $0.5 \mu \mathrm{M}$ of each of the primers $5^{\prime}$-ATATAAACTTGTGGTAGTTCCAGCTGGT- ${ }^{\prime}$ and $5^{\prime}$-ATCAAAGAATGGTCCTGCACC-3' $2.5 \mathrm{~mm} \mathrm{MgCl}_{2}, 100 \mu \mathrm{M}$ dNTPs, $1.25 \mathrm{U}$ FastStart TaqDNA polymerase (Roche Diagnostics GmBH, Mannheim, Germany) in the reaction buffer provided by the manufacturer. PCR cycling conditions were as follows: $95^{\circ} \mathrm{C}$ for $5 \mathrm{~min} ; 10$ cycles of $95^{\circ} \mathrm{C}$ for $20 \mathrm{~s}, 70^{\circ} \mathrm{C}$ for $20 \mathrm{~s}$ with a touchdown of $1^{\circ} \mathrm{C}$ per cycle; followed by a further 32 cycles of $95^{\circ} \mathrm{C}$ for $20 \mathrm{~s}, 60^{\circ} \mathrm{C}$ for $20 \mathrm{~s}, 72^{\circ} \mathrm{C}$ for $30 \mathrm{~s}$ prior to a final extension at $72{ }^{\circ} \mathrm{C}$ for $4 \mathrm{~min}$. Restriction fragment length polymorphism (RFLP) analysis was performed on amplicons at $55^{\circ} \mathrm{C}$ for $16 \mathrm{~h}$ with $10 \mathrm{U}$ of $B s l \mathrm{I}$ (NEB) according to the manufacturer's instructions. The resistance of PCR amplicons to BslI digestion indicated the presence of a mutation at the first or second base of Ki-ras codon 13.

The presence of MSI in each cell line was determined essentially as described (Hawkins and Ward, 2001) using primer sets for the pseudomonomorphic markers Bat25, Bat26 and Bat40 (Boland et al, 1998).

Assessment of ploidy was performed using the method of Taylor (1980). Briefly, washed tumour cells $\left(2.5 \times 10^{6}\right)$ were incubated at $4{ }^{\circ} \mathrm{C}$ for $10 \mathrm{~min}$ with a $1 \%$ Triton $\mathrm{X}-100$ solution containing $100 \mu \mathrm{g} \mathrm{ml}^{-1}$ of propidium iodide (Sigma, St. Louis, USA) in PBS. Cells were filtered through a nylon mesh to remove any clumps and incubated with DNAse-free RNAse for $30 \mathrm{~min}$ at $4{ }^{\circ} \mathrm{C}$ before analysis on the flow cytometer.

For methylation analyses, DNA was treated with sodium bisulphite and methylation-specific PCR (MSP) was performed to detect methylation of the $p 16$ promoter region (Herman et al, 1998; Hawkins et al, 2002). The methylation status of MINT 1, 2, 12 and 31 was performed according to the method of Toyota et al (1999a), and modified as previously described (Hawkins et al, 2002).

Methylation of $h M L H 1$ was examined by bisulphite-RFLP at two separate regions of the $h M L H 1$ promoter (A and C) purported to be associated with $h M L H 1$ silencing (Herman et al, 1998; Deng et al, 2002). The A region, encompassing base pairs 801-1050 of the $h M L H 1$ promoter, was amplified with the primers MLH-AF, $5^{\prime}$-TTAYGGGTAAGTYGTTTTGAYGTAGA-3' and MLH-AR, 5'CCTATACCTAATCTATCRCCRCCTCA- $3^{\prime}$. The $\mathrm{C}$ region, encompassing base pairs 1201-1450, was amplified with the primers MLH-CF, 5'-GGTTGGATATTTYGTATTTTTYGAG-3' and MLHCR, 5'-AATTACTAAATCTCTTCRTCCCTCC-3'. PCR was performed with $100 \mathrm{ng}$ of bisulphite-modified template with $1 \mu \mathrm{m}$ of each primer, $1.5 \mathrm{mM} \mathrm{MgCl} 2,250 \mu \mathrm{M}$ dNTPs and $1.5 \mathrm{U}$ FastStart TaqDNA polymerase (Roche Diagnostics $\mathrm{GmBH}$, Mannheim, Germany) in the recommended buffer. PCR cycling conditions were as follows: $95^{\circ} \mathrm{C}$ for $5 \mathrm{~min} ; 35$ cycles of $95^{\circ} \mathrm{C}$ for $30 \mathrm{~s}, 55^{\circ} \mathrm{C}$ for $45 \mathrm{~s}, 72^{\circ} \mathrm{C}$ for $30 \mathrm{~s}$ before a final extension at $72^{\circ} \mathrm{C}$ for $4 \mathrm{~min}$. The primers were designed to amplify both methylated and unmethylated template in the same reaction. Amplicons from methylated or unmethylated template were distinguished by restriction enzyme digestion with $10 \mathrm{U}$ of BstU1. Amplicons from unmethylated template will not cut; amplicons from methylated template will be 
digested. MLH1 expression was determined in parallel, in a subset of 20 cell lines, by Western blot, or immunostaining, as previously described (Ward et al, 2001; Li et al, 2002).

Methylation was reported for each locus as unmethylated, partially methylated or methylated. For p16, partial methylation was indicated by amplification in both the unmethylated and methylated MS-PCR reactions. For the MINT loci and $h M L H 1$, partial methylation was recorded when the digestion of PCR products was incomplete. For $h M L H 1$, the A and $\mathrm{C}$ regions were considered as one locus for analysis. Positive and negative controls were included in each procedure, and neither control revealed partial methylation in any assay. PCR reactions for all loci were performed from the same bisulphite-treated reaction in the majority of cases.

Categorical variables were compared using the $\chi^{2}$ test or the Fisher exact test as appropriate. A probability value of $<0.05$ was considered statistically significant. Statistical analysis was performed with SPSS statistical software V9.0 (SPSS Inc., Chicago, IL, USA).

\section{RESULTS}

The genetic and epigenetic changes in each cell line are detailed in Table 1. Overall, $87 \%$ (24 out of 30 ) of cell lines demonstrated methylation at two or more than six loci. The median number of methylated sites was 3, and this was observed in $44 \%$ of cell lines. Methylation at all six loci was seen in $7 \%$. The majority of primary tumours from HNPCC individuals displayed virtually no $\mathrm{CpG}$ island hypermethylation; 6 out of 7 had less than two of the loci methylated (Table 2). There were no significant differences, however, in the methylation propensity of sporadic cell lines $v s$ germline-derived cell lines. The frequency of hypermethylation at individual loci in both types, compared with primary tumours, is shown in Table 3. A significant increase in the frequency of methylation in cell lines compared to primary tumours is apparent $(P<0.01)$, regardless of germline status.

Table 2 Methylation profile of seven HNPCC patients

\begin{tabular}{|c|c|c|c|c|c|c|}
\hline \multirow{2}{*}{$\begin{array}{l}\text { HNPCC } \\
\text { patient }\end{array}$} & \multirow[b]{2}{*}{ MLHI-A } & \multirow[b]{2}{*}{ pl6 } & \multicolumn{4}{|c|}{ Methylation } \\
\hline & & & MINTI & MINT2 & MINTI2 & MINT3 I \\
\hline $1^{\mathrm{a}}$ & $U$ & $U$ & $M$ & $U$ & $U$ & $U$ \\
\hline $2^{\mathrm{a}}$ & $U$ & $\cup$ & $U$ & $U$ & $U$ & $U$ \\
\hline $3^{b}$ & $U$ & $\cup$ & $\cup$ & $\cup$ & U & $\cup$ \\
\hline $4^{b}$ & $U$ & $\cup$ & $\cup$ & $U$ & U & $\cup$ \\
\hline $5^{b}$ & $U$ & $\cup$ & $U$ & $U$ & $U$ & U \\
\hline $6^{b}$ & $M$ & $M$ & $M$ & $M$ & $\cup$ & $U$ \\
\hline $7^{b}$ & $M$ & $U$ & $U$ & $\cup$ & $\cup$ & $U$ \\
\hline
\end{tabular}

${ }^{a} \mathrm{hMLHI}$ germline. ${ }^{\mathrm{b}} \mathrm{hMSH} 2$ germline.
Methylation of $p 16$ (Figure 1A) was present in $71 \%$ (20/28) of cell lines assessable at this locus. One cell line, HCT116, showed partial methylation, and this has been shown previously to be because of the presence of a somatically mutated, but nonmethylated allele (Myohanen et al, 1998). Methylation at $p 16$ could not be reported in two cell lines, COLO741 and C170, owing to the lack of amplification of $p 16$, and this is likely because of biallelic loss of p16.

Methylation at the MINT loci (Figure 1B) was also a frequent finding in most of the cell lines, and this was usually observed as partial methylation. Partial methylation was considered real, and not an artefact of the bisulphite reaction, as PCR reactions for all the examined loci were usually performed from the same bisulphite reaction. In addition, peripheral blood control DNA was included at each step, along with all samples. Furthermore, overdigestion with excess enzyme performed on a subset of these partially methylated samples showed the same result. The frequencies of MINT methylation ranged from 53 to $68 \%$, and at all loci the frequency was significantly higher than that observed in sporadic CRC (Table 3). Like $p 16$, the frequency of methylation of MINT loci was increased in the cell lines irrespective of germline status; only one HNPCC primary tumour displayed some significant methylation.

Methylation of $h M L H 1$ at either the A or C region occurred in $30 \%$ of assessable cell lines (A, 28\%; C, 25\%), Figure 2A. Either full or partial methylation of both regions was strongly associated with loss of hMLH1 expression $(P<0.001)$, Figure 2B. Methylation of the $\mathrm{A}$ or $\mathrm{C}$ region alone did not affect the expression of MLH1. Only one cell line, LIM1215, showed a loss of hMLH1 expression in the absence of promoter methylation; however, this cell line has a germline $h M L H 1$ mutation, and probably $\mathrm{LOH}$ as the second hit (Whitehead et al, 1985).

There was only one cell line that showed no methylation at any of the six loci-SW1417. Although this unmethylated cell line was microsatellite stable (MSS), there was no significant association overall of MSI and the degree of methylation. There was no association between the methylation of any individual marker and the presence of MSI, with the exception of $h M L H 1$ (A or C region methylation, $P=0.03$ ). Apart from this expected association, methylation overall was found to occur with approximately equal frequency in MSS and MSI cell lines.

Microsatellite instability itself was detected in 14 cell lines (47\%), and a biallelic inactivation of APC in $18(60 \%)$. The two were not always mutually exclusive, with five cell lines (GP2D, HCT15N, LOVO, LS411 and DLD-1) showing both MSI and APC inactivation. As expected, the presence of MSI was highly associated with diploid cell lines $(P=0.001)$ and APC mutants were more likely to be aneuploid $(P=0.03)$. There was also a significant association between the presence of MSI and the loss of hMLH1 expression $(P=0.03)$.

A remarkably high rate of Ki-ras mutations was found in this data set. Of the 30 cell lines, $19(63 \%)$ were found to have a point mutation in either codon 12 or codon 13 of $\mathrm{Ki}$-ras (Figure 3). Codon 12 mutations occurred in $33 \%$, and this is comparable to the expected frequency for CRC (Andreyev et al, 2001). The

Table 3 Frequency of methylation at individual loci

\begin{tabular}{|c|c|c|c|c|c|}
\hline Loci & Sporadic CRC $^{\mathrm{a}} n=417$ (\%) & Cell line total $n=30$ & HNPCC $n=7$ & Cell line sporadic $n=22$ & Cell line HNPCC $n=8$ \\
\hline MINT-I & 25 & $63 \%(18)$ & $29 \%(2)$ & $59 \%(13)$ & $63 \%(5)$ \\
\hline MINT-2 & 29 & $57 \%(17)$ & $14 \%(1)$ & $55 \%(12)$ & $63 \%(5)$ \\
\hline MINT-3I & 14 & $53 \%(16)$ & $0 \%(0)$ & $46 \%(10)$ & $75 \%(6)$ \\
\hline $\mathrm{P} 16$ & 37 & $71 \%$ (20) & $14 \%(I)$ & $75 \%(15)$ & $63 \%(5)$ \\
\hline MLHI & 33 & $30 \%(9)$ & $29 \%(2)$ & $32 \%(7)$ & $25 \%(2)$ \\
\hline
\end{tabular}

${ }^{a}$ Hawkins et al (2002). 

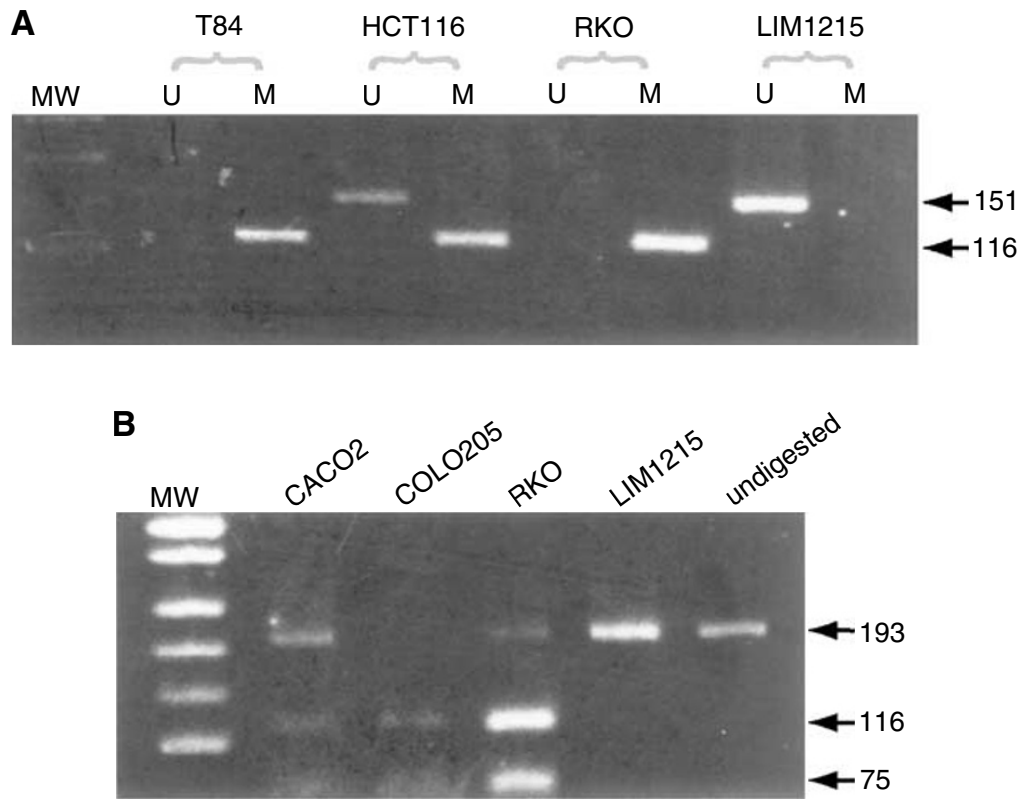

Figure I Analysis of methylation of p/6 and MINT loci in colorectal cell lines. (A) For p 16 promoter analysis, bisulphite-modified cell line DNA was amplified in separate reactions using primers specific for unmethylated $(U)$ or methylated $(M)$ template (methylation-specific PCR - MSP). Examples of methylated cell lines are T84 and RKO; these show amplification in the methylated reaction only. Presence of PCR product in both unmethylated and methylated reactions of HCTII6 is indicative of partial methylation at p/6. LIMI2I5 is shown as an example of a cell line unmethylated at p/6. (B) For analysis of methylation at MINT loci, bisulphite-modified DNA was first PCR amplified using appropriate loci-specific primers, and then the PCR products were digested with restriction enzymes that only cut amplicons generated from the methylated template. MINT2 is shown as a representative MINT locus. Resistance to digestion indicates an unmethylated template. Shown are cell lines with partial methylation at MINT 2, CACO2 and RKO, a fully methylated cell line, COLO205, and an unmethylated cell line LIMI2I5. Undigested amplicons are shown in the last lane. Molecular weight (MW) marker in A and B is pUCI9/Mspl.

proportion of cell lines harbouring mutations in codon 13 of Ki-ras in these cell lines was $30 \%$. This is considerably higher than the reported frequencies of around 8.6\% (Andreyev et al, 2001).

\section{DISCUSSION}

This study has revealed that methylation is very common in CRC cell lines. Methylation at most loci was observed at a significantly greater frequency than that expected from in vivo studies (Hawkins et al, 2002). The reason for the excessive levels of methylation in CRC cell lines as opposed to their primary counterparts is unclear.

Significantly lower levels of $\mathrm{CpG}$ island hypermethylation were observed in HNPCC primary tumours as compared to the sporadic tumours. This agrees with other reports on methylation in primary HNPCC tumours (Yamamoto et al, 2002); however, the cell lines do not parallel this difference. The propensity for hypermethylation in the cell lines did not differ between those derived from sporadic tumours, or HNPCC-derived tumours. The colorectal cell lines displayed significantly higher rates of methylation than that observed in primary CRC, whether it is sporadic, or associated with a germline mutation.

There may be several reasons for the high levels of methylation reported here. It is possible that it is acquired in vitro in a culture environment, which is in some way conducive to methylation. In support for this, one other study of methylation in 24 cell lines of various origins found that all of the cultured cell lines exhibited significantly more methylation at anonymous loci than the primary malignancies that they were derived from (Smiraglia et al, 2001). Using restriction genome landmark scanning (RLGS), Smiraglia and colleagues concluded, however, that the three colon cancer cell lines in their study were in fact the most similar to their primary counterparts. Other cell lines in this study, such as head and neck squamous cell carcinoma, had up to a 93-fold increase in hypermethylation of RLGS fragments. The authors conclude that most of the hypermethylation seen in cancer cell lines is because of an intrinsic property of cell lines, as opposed to the primary tumour from which they were derived. Tracking the epigenetic changes from individual tumours to their establishment as cell lines may distinguish between what, if any, is culture-induced methylation and what existed in vivo. Unfortunately, the most commonly used cell lines in CRC research have been established for over 20 years, and such epigenetic profiling is likely to be impossible now.

If methylation is occurring as a direct result of in vitro culture conditions, then it is likely to induce changes in the cells that render them nonrepresentative of the tumours from which they were derived. The tumour suppressor gene $p 16$ is commonly methylated in a wide variety of human primary tumours and cell lines (Herman et al, 1995; Merlo et al, 1995). Inactivation of p16 allows the cancer cell to escape senescence, and the normal cell cycle controls, to rapidly proliferate. If methylation and inactivation were to occur in vitro, the result would be altered growth characteristics, as compared to the parent tumour. Likewise, while the majority of the MINT sequences have not been described as genes, they may have important, albeit unknown, functions. MINT31 (also known as CACNA1G) has been mapped to a location of frequent $\mathrm{LOH}$ in cancer, and was found to be part of a gene encoding a T-type calcium channel (Toyota et al, 1999b). Such genes involved in modulating calcium signalling are likely to be important in cancer cell proliferation and apoptosis. Genes with important functions are often the targets of hypermethylation in cancer, with consequences affecting many cellular pathways. Besides methylation of $p 16$ and CACNA1G, a high rate of methylation of other important genes is observed in CRC. These include $h M L H 1$ (Kane et al, 1997; Herman et al, 1998) (mismatch repair), $O^{6} M G M T$ (Esteller et al, 2000b) (DNA repair) and p14/ARF 
A

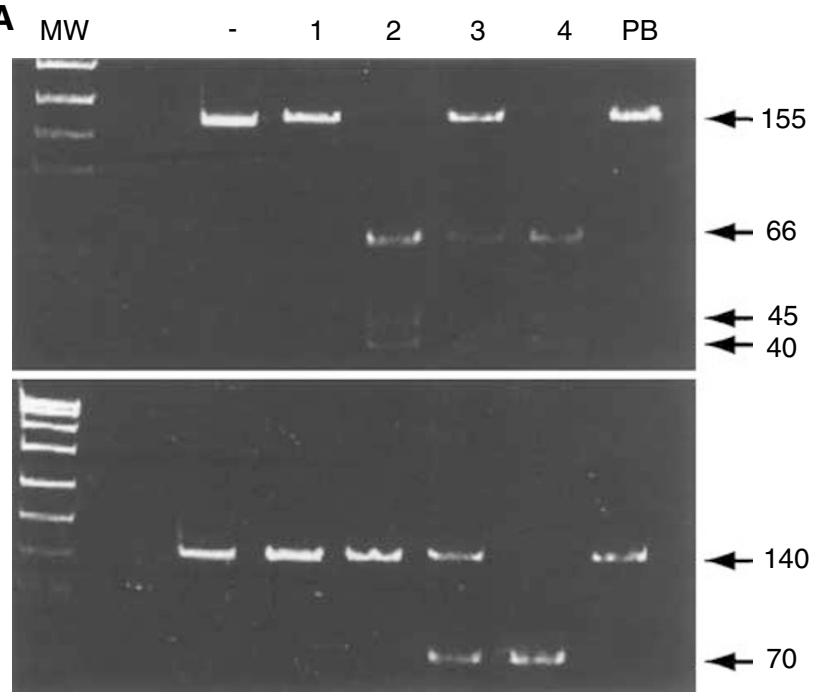

\begin{tabular}{llllll} 
A region & $U$ & $M$ & $P$ & $M$ & $U$ \\
\hline C region & $U$ & $U$ & $P$ & $M$ & $U$
\end{tabular}

B

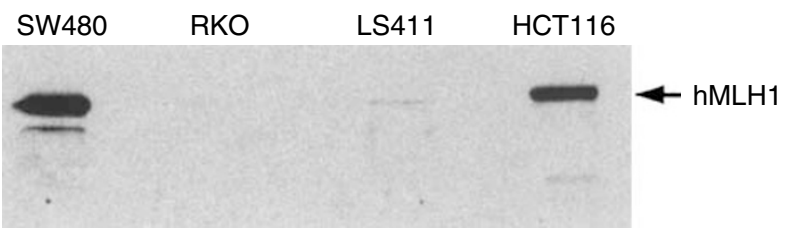

Figure 2 Analysis of $h M L H I$ methylation and expression in colorectal cell lines. (A) Both the $\mathrm{A}$ region (top panel) and $\mathrm{C}$ region (bottom panel) of the $h M L H I$ promoter were amplified from bisulphite-treated DNA. BstUI restriction enzyme digest was performed to distinguish amplicons from methylated or unmethylated template; BstUI will cut only amplicons generated from methylated template. Undigested PCR product is shown in the control lane (-). Lane I shows an example of a cell line unmethylated at both the A and C regions, DLDI. Lane 2 shows SW403 that is methylated at the A region, but not C. Lane 3 shows LS4II that is partially methylated at both regions and Lane 4 shows a fully methylated cell line, RKO. Peripheral blood (PB) DNA used as a control is always unmethylated at both the $\mathrm{A}$ and $\mathrm{C}$ regions. MW market is $\mathrm{PUCI} / \mathrm{Mspl}$. (B) Representative Western blot analysis of hMLHI expression in colorectal cell lines with various combinations of $A$ and $C$ region methylations. SW480 has no methylation at either region and has wild-type hMLHI. HCTII6 also is unmethylated at both regions; however, this cell line has a frameshift mutation in one allele of $h M L H I$, leading to a reduction in expression levels. Cell lines exhibiting either full (RKO) or partial (LS4II) methylation at both the $A$ and $C$ regions show a loss of hMLHI protein.

(Esteller et al, 2000a; Zheng et al, 2000) (p53 pathway). We have also found a high rate of methylation of $h M L H 1$ in the colon cancer cell lines although this was one marker that was not methylated at a higher rate in cell lines as opposed to primary tumours. It is possible that owing to the high rate of MSI in the cell lines, there is no selection pressure to methylate $h M L H 1$. Methylation at both the $\mathrm{A}$ and $\mathrm{C}$ regions of the promoter was strongly related to loss of hMLH1 expression. This is consistent with recent reports that only dense methylation of the $h M L H 1$ promoter is associated with gene silencing and loss of protein expression (Furukawa et al, 2002). The presence of partial methylation at both the $\mathrm{A}$ and $\mathrm{C}$ regions was also seen in cell lines lacking hMLH1 expression (LS411). This suggests that the high rate of partial methylation seen at the MINT loci is also functionally important. The study of $p 14$ methylation by Zheng and colleagues also identified partial methylation of p14

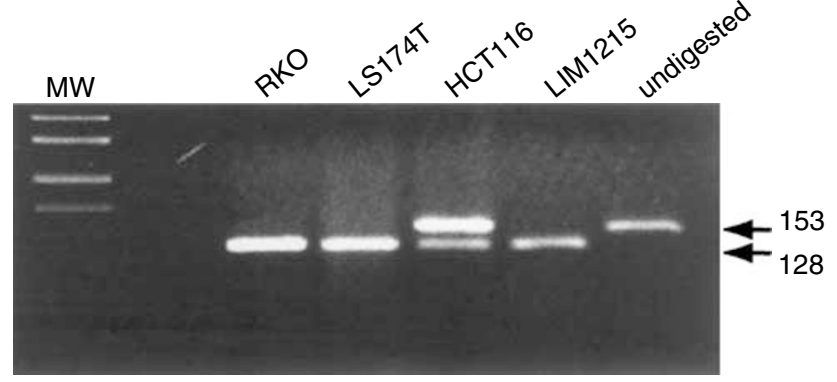

Figure 3 Detection of mutations in codon 13 of Ki-ras in colorectal cell lines. RFLP analysis was performed on Ki-ras PCR amplicons with the restriction enzyme Bsll. Mutations in the first or second base of codon 13 will abolish the Bsll site; therefore Ki-ras codon 13 mutants are resistant to digestion. Wild-type (WT) amplicons, and mutants other than codon I3, are fully digested by Bsll. Undigested amplicons are shown in the last lane. Both LIMI2I5 and RKO have WT Ki-ras; LSI74T is a codon 12 mutant; HCTI I6, displaying undigested product, is a codon 13 mutant. MW is pUC19/Mspl.

associated with reduced gene expression. Coincidentally, this study also revealed a greater percentage of methylated $p 14$ in cell lines $(40 \%)$ as opposed to primary colon cancers (18\%).

An alternative explanation for the high frequency of methylation observed in this study is that cell lines are more likely to be established from those tumours that are methylated in vivo. Tumour cell lines on the whole are difficult to establish, and perhaps the methylator type of tumour is more amenable or adaptable to culture conditions. Irrespective of the cause or timing of this aberrant methylation, there is evidence to suggest that it is important for CRC cell lines, and there is a strong selection pressure to maintain it. For example, many in vitro studies have shown that the methylation of various promoters is never $100 \%$ reversible. When cultured cells with $\mathrm{CpG}$ island methylation are exposed to demethylating 5-azacytidine treatments, methylation always returns upon withdrawal of the drug in a gene-specific manner, and has recently been shown to return, and be hereditable, in a parental allele-specific fashion (Li et al, 2002). This could argue that the hypermethylation present in these cell lines is not a phenomenon of culture, but rather a necessary and characteristic component of the cell line and the tumour from which it was derived.

Regardless of the cause of the excessive methylation in CRC cell lines, the end result is the same and CRC cell lines may only serve as a model for a subset of tumours. Considering that genes commonly methylated in CRC are often involved in cell proliferation, apoptosis and DNA repair, there is likely to be a very skewed bias of cell lines in many areas of research, not only methylation studies. A bias within these cell lines is further supported by the increased frequency of Ki-ras mutations and the over-representation of MSI.

MSI occurs at a frequency of $10-15 \%$ in sporadic CRC, but was observed at double the frequency in the sporadic cell lines. It was not surprising to find that the MSI cell lines in this study had a high frequency of methylation, as the association between the two phenomena has been well reported (Toyota et al, 1999a, 2000; Hawkins et al, 2002). What was more surprising was the high frequency of methylation in MSS cell lines. The fact that methylation can coexist with APC mutations in sporadic CRC has been reported by others, albeit with a lesser frequency (Gayet et al, 2001; Hawkins et al, 2002). These findings argue against the hypothesis that methylation is a third distinct pathway of colorectal tumourigenesis, and in favour of it being a feature of both standard pathways. Whether promoter methylation is a cause or a consequence of either pathway cannot be determined by this study. 
The high rate of Ki-ras codon 13 mutations in this study is also worthy of mention in terms of methylation. There is a reported association between Ki-ras mutations and highly methylated tumours (Toyota et al, 2000; Hawkins et al, 2002), however, codon 12 mutations are the predominating type in these studies of sporadic colorectal tumours. A high frequency of codon 13 mutations has only been reported once before, in a set of HNPCC tumours with MSI (Fujiwara et al, 1998). This is reflected in the germline-derived cell lines in this study; however, a significant proportion of codon 13 mutations also occurred in Ki-ras of nongermline cell lines. The increased frequency of codon 13 mutations in the cell lines, regardless of germline status, may in part be explained by a methylator phenotype. It has recently been shown that methylation of $O^{6}$-MGMT associates with Ki-ras mutations in CRC (Esteller et al, 2000b; Whitehall et al, 2001). This is likely because of the increased rate of $G$ to A transition mutations caused by the silencing, and subsequent deficiency, of $O^{6}$-MGMT. It is also worthy of note that $\mathrm{Ki}$-ras mutations have been found to associate with $p 16$ methylation in colorectal tumours and adenomas (Guan et al, 1999). These results together provide further evidence to support the notion that CRC cell lines are predominantly representative only of the methylator type of CRC.

Whether cause or consequence, epiphenomenon or true epigenetic change, the high frequency of methylation in these cell lines exists, and should be taken into account in studies on the biology of CRC. We would suggest that cell lines may be good models for the methylator type of CRC, and are not generally representative of sporadic CRC.

\section{ACKNOWLEDGEMENTS}

The authors thank E Mokany for technical assistance and $M$ Brattain for the cell line RKO.

\section{REFERENCES}

Ahuja N, Mohan AL, Li Q, Stolker JM, Herman JG, Hamilton SR, Baylin SB, Issa JP (1997) Association between CpG island methylation and microsatellite instability in colorectal cancer. Cancer Res 57: 3370 - 3374 Andreyev HJ, Norman AR, Cunningham D, Oates J, Dix BR, Iacopetta BJ, Young J, Walsh T, Ward R, Hawkins N, Beranek M, Jandik P, Benamouzig R, Jullian E, Laurent-Puig P, Olschwang S, Muller $\mathrm{O}$ Hoffmann I, Rabes HM, Zietz C, Troungos C, Valavanis C, Yuen ST, Ho JW, Croke CT, O’Donoghue DP, Giaretti W, Rappallo A, Russo A, Bazan V, Tanaka M, Omura K, Azuma T, Ohkusa T, Fujimori T, Ono Y, Pauly M, Faber C, Glaesener R, de Goeij AF, Arends JW, Andersen SN, Lovig T, Breivik J, Gaudernack G, Clausen OP, De Angelis PD, Meling GI, Rognum TO, Smith R, Goh HS, Font A, Rossel R, Sun XF, Zhang H, Benhattar J, Losi L, Lee JQ, Wang ST, Clarke PA, Bell S, Quirke P, Bubb VJ, Piris J, Cruickshank NR, Morton D, Fox JC, Al-Mulla F, Lees N, Hall CN, Snary D, Wilkinson K, Dillon D, Costa J, Pricolo VE, Finkelstein SD, Thebo JS, Senagore AJ, Halter SA, Wadler S, Malik S, Krtolica K, Urosevic N (2001) Kirsten ras mutations in patients with colorectal cancer: the 'RASCAL II' study. Br J Cancer 85: 692-696

Boland CR, Thibodeau SN, Hamilton SR, Sidransky D, Eshleman JR, Burt RW, Meltzer SJ, Rodriguez-Bigas MA, Fodde R, Ranzani GN, Srivastava S (1998) A National Cancer Institute Workshop on Microsatellite Instability for cancer detection and familial predisposition: development of international criteria for the determination of microsatellite instability in colorectal cancer. Cancer Res 58: 5248-5257

Deng G, Peng E, Gum J, Terdiman J, Sleisenger M, Kim YS (2002) Methylation of hMLH1 promoter correlates with the gene silencing with a region-specific manner in colorectal cancer. Br J Cancer 86: 574-579

Esteller M, Tortola S, Toyota M, Capella G, Peinado MA, Baylin SB, Herman JG (2000a) Hypermethylation-associated inactivation of p14(ARF) is independent of p16(INK4a) methylation and p53 mutational status. Cancer Res 60: 129-133

Esteller M, Toyota M, Sanchez-Cespedes M, Capella G, Peinado MA, Watkins DN, Issa JP, Sidransky D, Baylin SB, Herman JG (2000b) Inactivation of the DNA repair gene O6-methylguanine-DNA methyltransferase by promoter hypermethylation is associated with $G$ to $A$ mutations in Ki-ras in colorectal tumorigenesis. Cancer Res 60: 2368 2371

Fujiwara T, Stolker JM, Watanabe T, Rashid A, Longo P, Eshleman JR, Booker S, Lynch HT, Jass JR, Green JS, Kim H, Jen J, Vogelstein B, Hamilton SR (1998) Accumulated clonal genetic alterations in familial and sporadic colorectal carcinomas with widespread instability in microsatellite sequences. Am J Pathol 153: 1063-1078

Furukawa T, Konishi F, Masubuchi S, Shitoh K, Nagai H, Tsukamoto T (2002) Densely methylated MLH1 promoter correlates with decreased mRNA expression in sporadic colorectal cancers. Genes Chromosomes Cancer 35: $1-10$

Gayet J, Zhou XP, Duval A, Rolland S, Hoang JM, Cottu P, Hamelin R (2001) Extensive characterization of genetic alterations in a series of human colorectal cancer cell lines. Oncogene 20: 5025-5032
Guan RJ, Fu Y, Holt PR, Pardee AB (1999) Association of Ki-ras mutations with p16 methylation in human colon cancer. Gastroenterology 116: $1063-1071$

Hawkins N, Norrie M, Cheong K, Mokany E, Ku S, Meagher A, O'Connor T, Ward R (2002) Sporadic colorectal cancers with CpG island methylation: clinicopathological features and relationship to microsatellite instability. Gastroenterology 122: $1376-1387$

Hawkins NJ, Ward RL (2001) Sporadic colorectal cancers with microsatellite instability and their possible origin in hyperplastic polyps and serrated adenomas. J Natl Cancer Inst 93: 1307-1313

Herman JG, Merlo A, Mao L, Lapidus RG, Issa JP, Davidson NE, Sidransky $\mathrm{D}$, Baylin SB (1995) Inactivation of the CDKN2/p16/MTS1 gene is frequently associated with aberrant DNA methylation in all common human cancers. Cancer Res 55: 4525-4530

Herman JG, Umar A, Polyak K, Graff JR, Ahuja N, Issa JP, Markowitz S, Willson JK, Hamilton SR, Kinzler KW, Kane MF, Kolodner RD, Vogelstein B, Kunkel TA, Baylin SB (1998) Incidence and functional consequences of hMLH1 promoter hypermethylation in colorectal carcinoma. Proc Natl Acad Sci USA 95: 6870-6875

Ilyas M, Tomlinson IP, Rowan A, Pignatelli M, Bodmer WF. (1997) Betacatenin mutations in cell lines established from human colorectal cancers. Proc Natl Acad Sci USA 94: 10330-10334

Ionov Y, Peinado MA, Malkhosyan S, Shibata D, Perucho M (1993) Ubiquitous somatic mutations in simple repeated sequences reveal a new mechanism for colonic carcinogenesis. Nature 363: 558-561

Kane MF, Loda M, Gaida GM, Lipman J, Mishra R, Goldman H, Jessup JM, Kolodner R (1997) Methylation of the hMLH1 promoter correlates with lack of expression of hMLH1 in sporadic colon tumors and mismatch repair-defective human tumor cell lines. Cancer Res 57: $808-811$

Kinzler KW, Vogelstein B (1996) Lessons from hereditary colorectal cancer. Cell 87: $159-170$

Li H, Myeroff L, Kasturi L, Krumroy L, Schwartz S, Willson JK, Stanbridge E, Casey G, Markowitz S (2002) Chromosomal autonomy of hMLH1 methylation in colon cancer. Oncogene 21: $1443-1449$

Merlo A, Herman JG, Mao L, Lee DJ, Gabrielson E, Burger PC, Baylin SB, Sidransky D (1995) $5^{\prime}$ CpG island methylation is associated with transcriptional silencing of the tumour suppressor p16/CDKN2/MTS1 in human cancers. Nat Med 1: 686-692

Myohanen SK, Baylin SB, Herman JG (1998) Hypermethylation can selectively silence individual p16ink4A alleles in neoplasia. Cancer Res 58: $591-593$

Rowan AJ, Lamlum H, Ilyas M, Wheeler J, Straub J, Papadopoulou A, Bicknell D, Bodmer WF, Tomlinson IP (2000) APC mutations in sporadic colorectal tumors: a mutational 'hotspot' and interdependence of the 'two hits'. Proc Natl Acad Sci U S A 97: 3352-3357

Smiraglia DJ, Rush LJ, Fruhwald MC, Dai Z, Held WA, Costello JF, Lang JC, Eng C, Li B, Wright FA, Caligiuri MA, Plass C (2001) Excessive CpG island hypermethylation in cancer cell lines versus primary human malignancies. Hum Mol Genet 10: 1413-1419 
Taylor IW (1980) A rapid single step staining technique for DNA analysis by flow microfluorimetry. J Histochem Cytochem 28: 1021-1024

Toyota M, Ahuja N, Ohe-Toyota M, Herman JG, Baylin SB, Issa JP (1999a) CpG island methylator phenotype in colorectal cancer. Proc Natl Acad Sci USA 96: $8681-8686$

Toyota M, Ho C, Ohe-Toyota M, Baylin SB, Issa JP (1999b) Inactivation of CACNA1G, a T-type calcium channel gene, by aberrant methylation of its $5^{\prime} \mathrm{CpG}$ island in human tumors. Cancer Res 59: 4535-4541

Toyota M, Ohe-Toyota M, Ahuja N, Issa JP (2000) Distinct genetic profiles in colorectal tumors with or without the $\mathrm{CpG}$ island methylator phenotype. Proc Natl Acad Sci USA 97: 710-715

Ward R, Hawkins N, O'Grady R, Sheehan C, O'Connor T, Impey H, Roberts N, Fuery, C, Todd A (1998) Restriction endonuclease-mediated selective polymerase chain reaction: a novel assay for the detection of Ki-ras mutations in clinical samples. Am J Pathol 153: 373-379

Ward R, Meagher A, Tomlinson I, O'Connor T, Norrie M, Wu R, Hawkins N (2001) Microsatellite instability and the clinicopathological features of sporadic colorectal cancer. Gut 48: 821-829

Whitehall VL, Walsh MD, Young J, Leggett BA, Jass JR (2001) Methylation of O-6-methylguanine DNA methyltransferase characterizes a subset of colorectal cancer with low-level DNA microsatellite instability. Cancer Res 61: $827-830$

Whitehead RH, Macrae FA, St John DJ, Ma J (1985) A colon cancer cell line (LIM1215) derived from a patient with inherited nonpolyposis colorectal cancer. J Natl Cancer Inst 74: 759-765

Woodford-Richens KL, Rowan AJ, Gorman P, Halford S, Bicknell DC, Wasan HS, Roylance RR, Bodmer WF, Tomlinson IP (2001) SMAD4 mutations in colorectal cancer probably occur before chromosomal instability, but after divergence of the microsatellite instability pathway. Proc Natl Acad Sci USA 98: 9719-9723

Yamamoto H, Min Y, Itoh F, Imsumran A, Horiuchi S, Yoshida M, Iku S, Fukushima H, Imai K (2002) Differential involvement of the hypermethylator phenotype in hereditary and sporadic colorectal cancers with high-frequency microsatellite instability. Genes Chromosomes Cancer 33: $322-325$

Zheng S, Chen P, McMillan A, Lafuente A, Lafuente MJ, Ballesta A, Trias M, Wiencke JK (2000) Correlations of partial and extensive methylation at the p14(ARF) locus with reduced mRNA expression in colorectal cancer cell lines and clinicopathological features in primary tumors. Carcinogenesis 21: 2057-2064 